\title{
Use of pyruvate fermentation compared with tetrazolium reduction in the differentiation of group D streptococci
}

\author{
SHEENA A. WAITKINS \\ From the Cross Infection Reference Laboratory, Central Public Health Laboratory, Colindale Avenue, \\ London NW9 $6 \mathrm{HT}$
}

SUMMARY The reduction of 2,3,5 triphenyltetrazolium chloride in the original medium of Barnes (Journal of General Microbiology, 14, 57, 1956), and in a modified medium, was compared with the ability to ferment pyruvate as a means of separating Streptococcus faecalis from all other group D streptococci. The tetrazolium reduction test gave an occasional negative reaction with Str. faecalis strains. In addition, a number of strains gave a weakly positive reaction in the test, as did some strains of Str. faecium and Str. bovis. With some batches of tetrazolium, these weak reactions with Str. faecalis were so frequent that interpretation of the results was difficult. On the other hand, all Str. faecalis strains, and no other group D streptococci, gave a positive pyruvate-fermentation reaction in 48 hours.

Barnes (1956) showed that Streptococcus faecalis could be distinguished from other group D streptococci by its ability to reduce tetrazolium $(2,3,5$ triphenyltetrazolium chloride) to formazan on a glucose-containing agar medium with an initial pH of $6 \cdot 0$. On this medium it forms colonies that have a distinctive red, metallic sheen and are easily distinguished from the colourless colonies of Str. faecium and other group D streptococci. It was noted in the laboratory (L. C. Ball, personal communication, 1976) that Barnes' medium failed to support the growth of some strains of Str. bovis. The medium was, therefore, modified slightly by substituting Hedley Wright agar (Cowan, 1974) for infusion agar; this gave satisfactory growth of all the group D streptococci tested. Unfortunately batches of tetrazolium varied considerably in their ability to be reduced by Str. faecalis, and some strains of Str. faecium and Str. bovis gave a 'pink-red' coloration of their colonies. These factors tended to make the tetrazolium medium unsatisfactory for distinguishing Str. faecalis from other group D streptococci, the main consideration when dealing with clinical material from human sources.

In 1975, Gross et al, proposed a test for the fermentation of pyruvate as a means of distinguishing Str. faecalis from both Str. faecium and Str.

Received for publication 24 November 1977 bovis. The pyruvate-fermentation test was therefore compared with tetrazolium reduction as a means of distinguishing Str. faecalis from other group D streptococci.

\section{Media}

HORSE BLOOD AGAR

A layer of Hartley digest agar containing defibrinated horse blood $5 \% \mathrm{v} / \mathrm{v}$ (Oxoid) was poured over a layer of peptone-water agar (Cowan, 1974).

TODD-HEWITT BROTH

This was prepared as described by Cowan (1974).

INFUSION AGAR. pH 6.0

$0.455 \mathrm{~kg}$ of minced fat-free meat; $\mathrm{M}$ Peptone No. 1 (Lab. M), $10 \mathrm{~g}$; sodium chloride, 5.0 g; Davies agar, $10 \mathrm{~g}$; and 1 litre of cold tap water.

Minced fat-free meat was placed in the water to infuse overnight; the next morning the rest of the ingredients were added, and the mixture was boiled $\bar{\Phi}$ for 30 minutes, then filtered to remove the meat, $\stackrel{\infty}{+}$ which was discarded. The $\mathrm{pH}$ was adjusted to 6.0 and the medium was autoclaved for 20 minutes at $115^{\circ} \mathrm{C}$.

TETRAZOLIUM MEDIUM (Barnes, 1956)

This was infusion agar, $\mathrm{pH} 6 \cdot 0$, with the addition of 
glucose $1 \% \mathrm{w} / \mathrm{v}$ and $2,3,5$ triphenyltetrazolium chloride $0.02 \% \mathrm{w} / \mathrm{v}$ (Koch-Light Laboratories, Ltd).

Five batches of tetrazolium, nos. 40761, 44448, 55750, 69128, and 72919, were used.

HEDLEY WRIGHT AGAR. pH 6.0

This was prepared as described by Cowan (1974); the final $\mathrm{pH}$ was adjusted to $6 \cdot 0$.

\section{MODIFIED BARNES' TETRAZOLIUM MEDIUM}

This was Hedley Wright agar, pH 6.0, with the addition of glucose $1 \% \mathrm{w} / \mathrm{v}$ and $2,3,5$ triphenyltetrazolium chloride.

\section{PYRUVATE MEDIUM}

This contained Difco Tryptone, $10 \mathrm{~g}$; Difco Yeast Extract, $5 \mathrm{~g}$; potassium dihydrogen phosphate, $5 \mathrm{~g}$; sodium chloride, $5 \mathrm{~g}$; sodium pyruvate, $10 \mathrm{~g}$; bromothymol blue, $0.04 \mathrm{~g}$, and Davis Agar, $10 \mathrm{~g}$; distilled water, 1 litre.

This mixture was boiled for 5 minutes to dissolve the constituents completely, and the $\mathrm{pH}$ was adjusted to $7 \cdot 2-7 \cdot 4$. The medium was dispensed and bottled into $100 \mathrm{ml}$ amounts, and sterilised by autoclaving at $120^{\circ} \mathrm{C}$ for 15 minutes. When plates were required, the bottled medium was melted and poured; these poured plates could be stored at $4^{\circ} \mathrm{C}$ for at least four weeks. The medium was blue-green in colour.

\section{Cultures}

The group D streptococcal strains examined were:(1) from the National Collection of Type Cultures: Str. faecalis, nos. 2705, 5957, and 775; Str. faecium, nos. $7171,7176,7182,7379,7380$, and 7174 ; Str. durans, nos. 8129, 8130, 8174, and 8307; Str. bovis, no. 8140; and (2) a collection of 99 strains of Str. faecalis, 26 strains of Str. faecium, 1 strain of Str. durans, and 20 strains of Str. bovis received for identification in the laboratory and tested by the methods described by Parker and Ball (1976).

\section{Methods}

\section{CULTIVATION OF TEST ORGANISMS}

Both routine and NCTC strains were plated for purity on horse-blood agar and incubated overnight at $37^{\circ} \mathrm{C}$ in an atmosphere of $5 \% \mathrm{CO}_{2}$. A well isolated colony was subcultured into $10 \mathrm{ml}$ of Todd-Hewitt broth, which was incubated overnight at $37^{\circ} \mathrm{C}$ in $5 \% \mathrm{CO}_{2}$. Next morning a drop of turbid broth was dropped on to freshly poured pyruvate and tetrazolium plates, which were incubated aerobically at $37^{\circ} \mathrm{C}$ for two days. Controls were included: Str. faecalis no. NCTC2705, which gave strongly positive results in both tests, and Str. faecium no. NCTC7171, which gave negative results in both tests.

\section{RECORDING OF RESULTS}

Reduction of tetrazolium was graded as follows: +++ indicated the classical appearance of red colonies with a metallic sheen; ++ , deep pink colonies without the metallic sheen; + , faintly pink colonies; and -, no coloration of the colonies.

In the pyruvate-fermentation test a bright yellow coloration of the colonies and surrounding medium indicated acidification and was a positive result; no change in colour was a negative result. Weak reactions after 48 hours never occurred.

\section{Results}

Table 1 illustrates the variation of tetrazolium reduction by 102 strains of Str. faecalis (all of which survived $60^{\circ} \mathrm{C}$ for 30 minutes, failed to acidify arabinose, and possessed Lancefield group D antigen) with different batches of the chemical. It also compares the effect of different basal media, both Barnes' and the modified Hedley Wright agar, on the action of tetrazolium. In this series of tests the intensity of reduction was in general greater on the modified medium than on the original medium, but the latter gave slightly fewer completely negative 'false' reactions. The performance of both media was greatly influenced by the batch of 2, 3,5 triphenyltetrazolium chloride used. For example, in the modified media, batch no. 69128 gave good reduction with 90/102 Str. faecalis strains, and a further eight might have been accepted as giving a positive reaction $(++)$; only four of 102 organisms tested gave very feeble reactions $(+)$ that were potentially misleading, and none gave completely negative reactions. On the other hand, batch no. 72919 performed very poorly in both types of media and would have led to a great deal of difficulty in the interpretation of the results by inexperienced observers. Less than one-third of all the cultures gave strongly positive results $(+++)$ and nearly one-quarter gave equivocal results $(+)$. The other batches of tetrazolium tested, nos. 40761, 44448, and 55750, all performed moderately well, but a number of Str. faecalis strains gave equivocal or 'false' negative results on both types of medium.

Table 2 presents the frequency with which group D streptococci gave positive reactions of any strength from + to +++ . The strains tested were representative of the more commonly isolated species: Str. faecalis, Str. bovis biotype I (see Parker and Ball, 1976), Str. faecium, and Str. durans. Two 
Table 1 Variation of tetrazolium reduction by Str. faecalis with different batches of 2, 3, 5 triphenyltetrazolium chloride in modified Barnes' medium (MBM) and original Barnes' medium (BM)

\begin{tabular}{|c|c|c|c|c|c|c|c|c|c|c|}
\hline \multirow[t]{2}{*}{ Degree of reduction } & \multicolumn{10}{|c|}{$\begin{array}{l}\text { Number of cultures (of } 102 \text { tested) that gave the indicated degree of reduction on medium containing tetrazolium batc } \\
\text { number }\end{array}$} \\
\hline & $\begin{array}{l}40761 \\
M B M\end{array}$ & $\boldsymbol{B M}$ & $\begin{array}{l}44448 \\
M B M\end{array}$ & $\boldsymbol{B M}$ & $\begin{array}{l}55750 \\
M B M\end{array}$ & $\boldsymbol{B} M$ & $\begin{array}{l}69128 \\
M B M\end{array}$ & $B M$ & $\begin{array}{l}72919 \\
M B M\end{array}$ & $\boldsymbol{B M}$ \\
\hline $\begin{array}{r}++ \\
++ \\
+ \\
-\end{array}$ & $\begin{array}{r}68 \\
19 \\
13 \\
2\end{array}$ & $\begin{array}{r}55 \\
40 \\
5 \\
2\end{array}$ & $\begin{array}{r}61 \\
30 \\
11 \\
0\end{array}$ & $\begin{array}{r}70 \\
16 \\
14 \\
2\end{array}$ & $\begin{array}{r}70 \\
13 \\
15 \\
4\end{array}$ & $\begin{array}{r}56 \\
35 \\
10 \\
1\end{array}$ & $\begin{array}{r}90 \\
8 \\
4 \\
0\end{array}$ & $\begin{array}{r}80 \\
15 \\
7 \\
0\end{array}$ & $\begin{array}{r}32 \\
40 \\
22 \\
8\end{array}$ & $\begin{array}{l}29 \\
45 \\
24\end{array}$ \\
\hline
\end{tabular}

+++ red colonies with metallic sheen

++ deep pink colonies

+ faintly rose-pink colonies

- no pink or red coloration

$M B M=$ modified Barnes' medium

$B M=$ original Barnes' medium (see text)

Table 2 Frequency of positive tetrazolium reduction tests (of any strength from + to +++ ) and of positive pyruvate-fermentation tests given by strains of various group D streptococci

\begin{tabular}{|c|c|c|c|c|c|c|c|c|c|c|c|c|}
\hline \multirow[t]{3}{*}{ Streptococcus } & \multirow{3}{*}{$\begin{array}{l}\text { No. of cultures } \\
\text { tested }\end{array}$} & \multicolumn{11}{|c|}{ Number of cultures of the indicated streptococci that gave a positive reaction on medium containing: } \\
\hline & & \multicolumn{10}{|c|}{ Tetrazolium, batch no. } & \multirow{2}{*}{$\begin{array}{l}\text { Number of cultures } \\
\text { fermenting pyruvate }\end{array}$} \\
\hline & & $\begin{array}{l}40761 \\
M B M\end{array}$ & $\boldsymbol{B}$ & $\begin{array}{l}44448 \\
M B M\end{array}$ & $\boldsymbol{B}$ & $\begin{array}{l}55750 \\
M B M\end{array}$ & $\boldsymbol{B}$ & $\begin{array}{l}69128 \\
M B M\end{array}$ & $\boldsymbol{B}$ & $\begin{array}{l}72919 \\
M B M\end{array}$ & $\boldsymbol{B}$ & \\
\hline $\begin{array}{l}\text { faecalis } \\
\text { faecium } \\
\text { bovis biotype I } \\
\text { durans }\end{array}$ & $\begin{array}{r}102 \\
30 \\
21 \\
5\end{array}$ & $\begin{array}{r}100 \\
2 \\
1 \\
0\end{array}$ & $\begin{array}{r}100 \\
2 \\
1 \\
0\end{array}$ & $\begin{array}{r}102 \\
2 \\
1 \\
0\end{array}$ & $\begin{array}{r}100 \\
2 \\
1 \\
0\end{array}$ & $\begin{array}{r}98 \\
2 \\
1 \\
0\end{array}$ & $\begin{array}{r}101 \\
3 \\
1 \\
0\end{array}$ & $\begin{array}{r}102 \\
2 \\
1 \\
0\end{array}$ & $\begin{array}{r}102 \\
2 \\
1 \\
0\end{array}$ & $\begin{array}{r}94 \\
2 \\
1 \\
0\end{array}$ & $\begin{array}{r}98 \\
2 \\
1 \\
0\end{array}$ & $\begin{array}{r}102 \\
0 \\
0 \\
0\end{array}$ \\
\hline
\end{tabular}

strains of Str. faecium (no. NCTC7182 and one routine isolate) and one of Str. bovis biotype I gave 'false' positive reactions indicated by pink or red colonies. Indeed, Str. faecium no. NCTC7182 gave a ++ reaction and would certainly have been misclassified as a Str. faecalis if tetrazolium reduction had been used as the identification criterion.

The variation of the basal medium had little effect on the frequency of 'false' positives. On the other hand, all Str. faecalis strains and none of other group D streptococci tested gave a positive pyruvate-fermentation test.

\section{Discussion}

The group D streptococci of importance in medical microbiology are Str. faecalis and Str. bovis. These are unlikely to be confused, because Str. bovis usually forms minute colonies and is highly sensitive to benzyl penicillin in a disc-diffusion test. The main problem, therefore, is to separate Str. faecalis from the rest of the enterococci (especially Str. faecium and Str. durans), and the tellurite resistance or the tetrazolium reduction tests are usually used for this purpose in the routine lab- oratory. In our earlier experience, the latter gave a more clear-cut differentiation than the former, and this test plus the acidification of arabinose, melibiose, and melezilose greatly facilitated presumptive identification of these group D streptococci. However, we were from time to time troubled by batches of 2,3,5 triphenyltetrazolium chloride that gave a number of feeble or even negative reactions with strains of streptococci that appeared to be in every respect true Str. faecalis.

Gross et al. (1975) proposed an alternative reaction which utilised the ability of Str. faecalis to ferment pyruvate. These authors found that this metabolic ability was exclusive to Str. faecalis among the group D streptococci. They did observe, however, that some strains of Str. avium gave a feeble positive reaction after 72 hours, but these same strains were negative if incubation was for only 48 hours. They did not test any group D streptococci that gave equivocal results with tetrazolium reduction, but in this study $I$ included a number of 'problem' strains. From the results presented I conclude that pyruvate-fermentation is an excellent key test to use in the differentiation of Str. faecalis from other group D streptococci. 


\section{References}

Barnes, E. M. (1956). Tetrazolium reduction as a means of differentiating Streptococcus faecalis from Streptococcus faecium. Journal of General Microbiology, 14, 57-68.

Cowan, S. T. (1974). Cowan and Steel's Manual for the Identification of Medical Bacteria, 2nd edition. Cambridge University Press, London.

Gross, K. C., Houghton, M. P., and Senterfit, L. B. (1975). Presumptive speciation of Streptococcus bovis and other group D streptococci from human sources by using arginine and pyruvate tests. Journal of Clinical Microbiology, 1, 54-60.

Parker, M. T., and Ball, L. C. (1976). Streptococci and aerococci associated with systemic infection in man. Journal of Medical Microbiology, 9, 275-302.

Requests for reprints to: Dr Sheena A. Waitkins, Public Health Laboratory, Fazakerley Hospital, Lower Lane, Liverpool L9 7AL.

\section{The June 1978 Issue}

\section{THE JUNE 1978 ISSUE CONTAINS THE FOLLOWING PAPERS}

Enzyme immunoassays with special reference to ELISA techniques A. VOLLER, A. BARTLETT, AND D. E. BIDWELL

Evaluation of the single radial haemolysis (SRH) technique for rubella antibody measurement $\mathbf{s}$. M. RUSSELL, SANDRA R. BENJAMIN, MOYA BRIGGS, MARY JENKINS, P. P. MORTIMER, AND SHEILA B. PAYNE

Measurement of total haemolytic complement activity in body fluids W. M. STRONG, D. J. LEA, AND D. J. WARD

Determination of antibiotic sensitivities by the Sensititre system IAN PHILLIPS, CHRISTINE WARREN, AND PAMELA M. WATERWORTH

An assessment of the Sensititre method for determining minimum inhibitory and bactericidal concentrations ANGELA H. PYKETT

Phagocytosis and killing of staphylococci by human polymorphonuclear and mononuclear leucocytes H. A. Verbrugh, R. PETERS, P. K. PETERSON, AND J. VERHOEF

Serum immunoglobulin concentrations before and after splenectomy in patients with homozygous $\beta$-thalassaemia M. CONSTANTOULAKIS, D. TRICHOPOULOS, O. AVGOUSTAKI, AND J. ECONOMIDOU
Cytological basis of histological typing of diffuse Hodgkin's disease A. E. LIVESEY, FIONA I. SUTHERLAND, R. A. BROWN, J. SWANSON BECK, J. B. MACGILLIVRAY, AND W. SLIDDERS

A case of Lennert's lymphoma J. B. MacGILlivRAY AND W. G. MACINTOSH

Overlap in the spectrum of non-specific inflammatory bowel disease - 'colitis indeterminate' ASHLEY B. PRICE

Ontogeny of actin and microsomal antigens in gastric parietal cells R. CEREDIG AND B. H. TOH

Use of a mucolytic agent (Cytoclair) in the preparation of cell material for the detection of malignant cells in sputum J. M. GRAINGER AND O. A. N. HUSAIN

Ectopic ACTH syndrome: clinicopathological correlations W. SINGER, K. KOVACS, N. RYAN, AND E. HORVATH

A case of type III hyperlipoproteinaemia studied by acrylamide gel gradient electrophoresis M. Y. CHEW, J. M. GUTMAN, AND J. GREEN

\section{Technical method}

Rapid acetoacetate analysis on the LKB 8600 Reaction Rate Analyser D. F. DAVIDSON

Book reviews

Copies are still available and may be obtained from the PUBLISHING MANAGER, BRITISH MEDICAL ASSOCIATION, TAVISTOCK SQUARE, LONDON WC1H 9JR, price $£ 3 \cdot 00$, including postage 